\section{Utjecaj pandemije COVID-19 na burzovne indekse odabranih zemalja $^{1}$}

\section{Impact of the COVID-19 pandemics on stock market indices in selected economies}

\section{Sažetak}

Cilj ovog rada je istražiti utjecaj širenja koronavirusa na kretanje značajnih burzovnih indeksa izabranih gospodarstava. Prikupljeni su podaci o kretanju broja novozaraženih, cijepljenih i preminulih osoba te podaci o učestalosti pretraživanja ključnih riječi Koronavirus, Pandemija i Lockdown, kako bi se analizirao njihov učinak na promjene u burzovnim indeksima na dnevnoj i tjednoj bazi. Nakon provedene korelacijske analize, zaključuje se kako brojevi novozaraženih, cijepljenih i preminulih osoba nisu značajno utjecali na pad vrijednosti indeksa koji je većinom započeo i prije nego je zabilježen prvi slučaj u toj zemlji. Ipak, pretraživanje ključnih riječi imalo je utjecaja na promjene indeksa,što se vidi u tome da su indeksi učestalosti pretraživanja ključnih riječi ostvarili najveće godišnje vrijednosti u tjednima prije pada vrijednosti indeksa. Nadalje, potvrđena je i povezanost razlike između očekivanog i ostvarenog bruto domaćeg proizvoda i kretanja burzovnih indeksa te se uočava umjereno jaka i jaka pozitivna veza. Rezultati istraživanja potvrđuju da je ovakva analiza mogla pomoći u predviđanju kratkoročnih trendova analiziranih tržišnih indeksa.

Ključne riječi: COVID-19, korelacijska analiza, burzovni indeks, pandemija

JEL klasifikacija: C32, G15

\section{Abstract}

The aim of this paper is to investigate the impact of the coronavirus pandemic on trends in key stock market indices of selected economies. Data on the number of newly infected, vaccinated, and deceased persons, and on the frequency of searches for the words Coronavirus, Pandemic and Lockdown were collected to analyze their effect on changes in stock market indices on a daily and weekly basis. The results of the correlation analysis show that numbers of newly infected, vaccinated, and deceased persons did not significantly affect the decline of most of the indices, which had started even before the first recorded case in that economy. Still, keyword searches had an effect on the movement of indices, which is reflected in the fact that the frequency indices of searches for keywords reached maximum annual values in the weeks preceding the decline of indices. The correlation between the expected and realized gross domestic product and the movement of stock exchange indices was also confirmed, where a moderately strong and strong positive relationship is observed. The results of the research confirm that conducting such an analysis could have been used in the prediction of short-term trends in

1 Ovaj rad temelji se na istraživanju iz diplomskog rada Brune Šegovića, mag. oec. pod nazivom „Utjecaj COVID-19 pandemije na tržišta kapitala u odabranim zemljama“.

\section{Mihovil Anđelinović}

Izv. prof.dr.sc.

Ekonomski fakultet Sveučilišta u Zagrebu

E-mail: mandelinovic@efzg.hr

\section{Ana Pavković}

Dr.sc.

Ekonomski fakultet Sveučilišta u Zagrebu

E-mail:ana.pavkovic@efzg.hr

\section{Bruno Šegović, mag. oec.}

Zagrebačka banka d.d.

E-mail: brunosegovic1911@gmail.com

\section{Mihovil Anđelinović}

Assoc. prof.

Faculty of Economics and Business, University of Zagreb

E-mail:mandelinovic@efzg.hr

\section{Ana Pavković}

$\mathrm{PhD}$

Faculty of Economics and Business,

University of Zagreb

E-mail:ana.pavkovic@efzg.hr

\section{Bruno Šegović, mag. oec.}

Zagrebačka banka d.d.

E-mail: brunosegovic1911@gmail.com 
Anđelinović, M., Pavković, A., Šegović, B.

Utjecaj pandemije COVID-19 na burzovne indekse odabranih zemalja

the analyzed market indices.Investments in fixed assets increase exports of a not fully export-oriented company more than a fully export-oriented company.

Keywords: COVID-19, correlation analysis, stock market index, pandemic

JEL classification: $\mathrm{C} 32, \mathrm{G} 15$

\section{Uvod}

Pandemija COVID-19 drastično je utjecala na sve aspekte modernog društva. Pojava pandemije dovela je nositelje politike pred težak odabir: zaustavljanje gospodarske aktivnosti i odlazak u takozvani lockdown s ciljem smanjenja broja zaraženih ili ne-zatvaranje gospodarstva pri čemu se riskira eksponencijalni rast broja zaraženih i broja umrlih. Najveći broj zemalja odabrao je opciju stopiranja gospodarstava, što je dovelo do nužnog rasta stope nezaposlenosti, smanjenja bruto domaćeg proizvoda te zatvaranja brojnih poduzeća (Our World in Data, 2021.). Stanje gospodarstava ogleda se u kretanju burzovnih indeksa koji su, pod teretom krize, naglo potonuli $s$ rekordnih vrijednosti zabilježenih prije krize Volatilnost je dosegla iznimne razine pa je vrlo nezahvalno predviđati buduće trendove, ali je moguće prepoznati varijable koje su utjecale na burzovne indekse (NASDAQ, 2021.; S\&P Global, 2021.; Wall Street Journal, 2021.; Yahoo Finance, 2021.; Zagrebačka burza, 2021.).

Temeljni cilj ovog rada je ispitati učinak indikatora pandemije te učestalosti pretraživanja ključnih riječi vezanih uz pandemiju na kretanje burzovnih indeksa u Sjedinjenim Američkim Državama, Kini, Europskoj uniji i Republici Hrvatskoj. Za prikaz američkog gospodarstva odabrani su burzovni indeksi Dow Jones Industrial Average 30 (DJIA30) i Standard and Poor's 500 (S\&P500) kao pokazatelji kretanja na Njujorškoj burzi (engl. New York Stock Exchange, NYSE), a indeks NASDAQ Composite kretanja na burzi NASDAQ (engl. NASDAQ Stock Exchange, NASDAQ) (NASDAQ, 2021.; S\&P Global, 2021.; Wall Street Journal, 2021.). Nadalje, kinesko tržište predstavljeno je indeksom SSE Composite koji je najšire korišten indeks financijskog sustava Narodne Republike Kine i odražava 20-godišnji rast kineskog tržišta. Najveća europska burza Euronext (engl. European Exchange Technology) čini grupaciju burzi najvećih gradova Europske unije, a za potrebe ovog istraživanja upotrijebljen je indeks EURO STOXX 50, kreiran od strane Deutsche Börse (Yahoo Finance, 2021.). Konačno, hrvatsko tržište se prikazuje najkorištenijim indeksom zagrebačke burze, a to je CROBEX.

Empirijsko istraživanje provodi se na temelju dnevnih i tjednih podataka koji pokazuju razmjer i ozbiljnost krize pa se samim time mogu razmatrati kao determinanta porasta volatilnosti burzovnih indeksa. Koristi se dnevni broj novozaraženih i umrlih radi predodžbe širenja virusa i kao temelja za oblikovanje očekivanja o političkim mjerama u budućnosti. Tjedni broj novozaraženih i umrlih upotrijebljen je radi poništavanja utjecaja pojedinih dana u kojima je bio manji broj slučajeva zbog manjeg broja testiranja. U 2021. godini upotrijebljen je i broj cijepljenih osoba. Osim toga, proučava se i utjecaj pretraživanja ključnih riječi koje imaju direktnu vezu sa širenjem virusa: Koronavirus, Pandemija i Lockdown. U analizi se pretpostavlja da veći broj pretraživanja ovih riječi znači veći interes i saznanja građana o koronavirusu. Uz povećanu osviještenost dolazi i bojazan od zaraze pa sukladno tome, građani manje ulaze u socijalne kontakte, što se negativno odražava na poslovanje poduzeća. U radu se također proučavaju podaci o bruto domaćem proizvodu, a kako njegovo kretanje znatno ovisi o ograničenjima vezanim uz COVID-19, mogu se dogoditi valovi optimizma ili pesimizma ukoliko stvarni BDP bude bolji/lošiji od očekivanog BDP-a. Korelacija indeksa s BDP-om uzima se i na dnevnoj i na 5-dnevnoj bazi, kako bi se mogao iskazati njegov puni utjecaj. Samo za američko gospodarstvo, proučene su i varijable tjednog broja novonezaposlenih i kretanja ključnih kamatnih stopa jer jedino SAD vodi takvu statistiku (FRED, 2021.). Rast broja novonezaposlenih osoba posljedica je zatvaranja gospodarstva, zbog čega je ta varijabla zanimljiva za ovu analizu, dok kretanja kamatnih stopa predstavljaju odgovor središnje 
banke na krizu i značaj očuvanja financijske stabilnosti.

Osnovna je pretpostavka rada da vrijednosti burzovnih indeksa jako reagiraju na novosti 0 pandemiji, što znači da se pretpostavlja da postoji jaka povezanost između broja osoba koje su se zarazile, cijepile ili preminule i kretanja na tržištima kapitala, odnosno da postoji jaka korelacija i između učestalosti pretraživanja pojmova vezanih uz pandemiju koronavirusa i kretanja na tržištima kapitala. Doprinos ovog rada ogleda se u analizi korelacija između odabranih burzovnih indeksa i pokazatelja pandemije, kao i burzovnih indeksa i pretraživanja ključnih pojmova vezanih uz pandemiju radi identifikacije njihovog značaja za burzovna kretanja.

Rad je strukturiran u pet poglavlja. Nakon uvodnog poglavlja, u drugom poglavlju daje se pregled empirijskih istraživanja o učincima pandemije koronavirusa na tržišta kapitala. U trećem poglavlju opisani su upotrijebljeni podaci. Četvrto poglavlje sadrži rezultate korelacijske analize, dok peto poglavlje donosi zaključke rada.

\section{Pregled literature}

Usporedno sa širenjem pandemije COVID-19, „eksplodirala“ su i znanstvena istraživanja svih segmenata pandemije. Učinci pandemije na tržišta kapitala koji se proučavaju u ovom radu bili su predmetom istraživanja u brojnim drugim radovima.

Ashraf (2020.) je istraživao reakciju tržišta na promjenu broja zaraženih i umrlih te potvrđuje kako su prinosi na burzi pali kako se povećavao broj potvrđenih slučajeva i da su burze proaktivnije reagirale na rast broja potvrđenih slučajeva u odnosu na rast broja smrtnih slučajeva. Sveukupno, rezultati sugeriraju da burze brzo reagiraju na pandemiju COVID-19 i taj odgovor varira tijekom vremena ovisno o fazi izbijanja. Baker i suradnici (2020.) ispituju volatilnost tržišta dionica SAD-a na temelju dnevnih naslova vijesti i pokazuju da COVID-19 ima neviđeni učinak na volatilnost tržišta dionica, osobito nakon 24. veljače 2020. Albulescu (2021.) je analizirao učinak službenih objava 0 broju novozaraženih i broju umrlih na volatilnost tromjesečnog indeksa S\&P 500. Na temelju regresijske analize pokazao je da produljenje koronakrize pojačava volatilnost na američkom tržištu. Xu (2021.) istražuje utjecaj neizvjesnosti vezane uz pandemiju na povrat na dionica. Koristeći dnevne podatke iz Kanade i SAD-a, pokazuje da postoji negativan učinak povećanja broja slučajeva COVID-19 na burzi općenito.

Lyocsa i Molnar (2020.) bave se utjecajem straha od koronavirusa na tržišta kapitala te proučavajući opseg Google pretraživanja pojmova vezanih uz pandemiju pokazuju da se kretanje indeksa može uvelike objasniti varijablama pandemije. Just i Echaust (2020.) ispituju isto na uzorku dvanaest zemalja i pokazuju značaj straha od koronavirusa za volatilnost tržišta u Italiji koja je bila najjače pogođena zemlja Europske unije. Bannigidadmath i suradnici (2021.) te Scherf i suradnici (2021.) istražuju učinak lockdowna na globalna tržišta kapitala i uglavnom pokazuju negativan učinak na svjetskoj razini, dok su reakcije tržišta na primjerice, zabrane putovanja bile neznačajne.

He i suradnici (2020.) te Senol i Zeren (2020.) su proučavali učinke pandemije COVID-19 na svjetska gospodarstva i tržišta kapitala te zaključuju da ova pandemija ima negativan utjecaj na tržišta kapitala, jednako kako je u empirijskoj literaturi potvrđen raniji negativan učinak pandemija na tržišta kapitala i gospodarski sustav (primjerice, Bloom i Mahal, 1997.; Nippani i Washer, 2004.; Armien i suradnici, 2008.; Giudice i Paltrinieri, 2017.; Chen i suradnici, 2018.; Estrada i suradnici, 2020.). Sergi i suradnici (2021.) ispituju učinak Barrovog indeksa bijede (engl. Barro Misery Indeks, BMI) i broja smrti od novog koronavirusa (COVID-19) na prinose i volatilnost burzi. Pokazuju da povećanje BMI zajedno s povećanjem postotka slučajeva COVID-19 negativno utječe na povrat dionica i povećava volatilnost, što je vođeno promjenama realnog BDP-a, stopom nezaposlenosti i dugoročne kamatne stope umjesto stopa inflacije, posebno za razvijene zemlje.

\section{Empirijski podaci}

U radu se ispituje korelacija između nekoliko burzovnih indeksa $s$ varijablama broja novozaraženih, umrlih i cijepljenih osoba, kao i $s$ indeksima učestalosti pretraživanja najbitnijih pojmova vezanih uz pandemiju, kako bi se ustanovio njihov značaj za kretanja na burzama. Tablica 1. daje pregled upotrijebljenih varijabli i izvore podataka.
Anđelinović, M., Pavković, A., Šegović, B.

Utjecaj pandemije COVID-19 na burzovne indekse odabranih zemalja 
Anđelinović, M., Pavković, A., Šegović, B.

Utjecaj pandemije COVID-19 na burzovne indekse odabranih zemalja
Tablica 1. Popis upotrijebljenih varijabli

\begin{tabular}{|c|c|c|}
\hline Varijabla & Opis & lzvor \\
\hline Dow Jones Industrial Average 30 & $\begin{array}{l}\text { Dow Jones Industrial Average } 30 \text { indeks sadrži } 30 \text { velikih } \\
\text { američkih poduzeća koje kotiraju na NYSE. }\end{array}$ & $\begin{array}{l}\text { Wall Street Journal } \\
\qquad \text { (2021.) }\end{array}$ \\
\hline Standard \& Poor's 500 & $\begin{array}{l}\text { Standard \& Poor's } 500 \text { obuhvaća } 500 \text { najvećih poduzeća na } \\
\text { NYSE te pokriva približno } 80 \% \text { ukupne tržišne kapitalizacije } \\
\text { te burze. }\end{array}$ & S\&P Global (2021.) \\
\hline NASDAQ Composite & $\begin{array}{l}\text { U NASDAQ Composite indeksu su sadržane gotovo sve kompa- } \\
\text { nije izlistane na NASDAQ burzi, a kako su gotovo sva izlistana } \\
\text { poduzeća na burzi dio indeksa, zapravo je najviše oslonjen na } \\
\text { brzorastuća poduzeća iz IT sektora. }\end{array}$ & NASDAQ (2021.) \\
\hline EURO STOXX 50 & $\begin{array}{l}\text { EURO STOXX } 50 \text { čini glavni europski indeks koji uključuje } \\
50 \text { blue-chip poduzeća iz } 8 \text { članica Eurozone: Belgije,Finske, } \\
\text { Francuske, Nizozemske, Njemačke, Irske, Italije i Španjolske. }\end{array}$ & Yahoo Finance (2021.) \\
\hline CROBEX & $\begin{array}{l}\text { Najkorišteniji indeks Zagrebačke burze u kojem su sadržane } \\
\text { sve likvidnije i značajnije dionice, a broj sastavnica varira od } \\
15 \text { do } 25 \text {. }\end{array}$ & $\begin{array}{l}\text { Zagrebačka burza } \\
\text { (2021.) }\end{array}$ \\
\hline Broj novozaraženih & $\begin{array}{l}\text { Broj novozaraženih osoba predstavlja broj novih zabilježenih } \\
\text { slučajeva i uzima se na dnevnoj i tjednoj bazi. }\end{array}$ & $\begin{array}{l}\text { Our World in Data } \\
\qquad \text { (2021.) }\end{array}$ \\
\hline Broj umrlih & $\begin{array}{l}\text { Broj umrlih osoba predstavlja broj smrtnih slučajeva koji se } \\
\text { povezuju s COVID-19 i uzima se na dnevnoj i tjednoj bazi. }\end{array}$ & $\begin{array}{l}\text { Our World in Data } \\
\text { (2021.) }\end{array}$ \\
\hline Broj cijepljenih & $\begin{array}{l}\text { Broj cijepljenih osoba koristi se od 2021. godine jer cjepivo nije } \\
\text { ranije bilo dostupno. }\end{array}$ & $\begin{array}{l}\text { Our World in Data } \\
\text { (2021.) }\end{array}$ \\
\hline $\begin{array}{l}\text { Razlike stvarnog i očekivanog } \\
\text { bruto domaćeg proizvoda }\end{array}$ & $\begin{array}{l}\text { Odnosi se na informacije o kretanju bruto domaćeg proizvoda u } \\
\text { odnosu na potencijalnu razinu. }\end{array}$ & $\begin{array}{l}\text { Investing.com (2021.) } \\
\text { i Trading Economics } \\
\text { (2021.) }\end{array}$ \\
\hline Broj novonezaposlenih & $\begin{array}{l}\text { Odnosi se na broj osoba u Sjedinjenim Američkim Državama } \\
\text { koje su ostale bez posla u određenom tjednu i prikazuje se } \\
\text { jedino za SAD. }\end{array}$ & $\begin{array}{l}\text { Federal Reserve Econo- } \\
\text { mic Data (2021.) }\end{array}$ \\
\hline $\begin{array}{l}\text { Razlike stvarnih i očekivanih } \\
\text { kamatnih stopa }\end{array}$ & $\begin{array}{l}\text { Odnosi se na razlike stvarnih i očekivanih kamatnih stopa FED-a } \\
\text { i računa se samo za SAD. }\end{array}$ & Investing.com (2021.) \\
\hline Koronavirus & $\begin{array}{l}\text { Indeks učestalosti pretraživanja riječi Koronavirus pokazuje broj } \\
\text { pretraživanja u Google tražilici, što pokazuje interes za ovom } \\
\text { temom a Google ih razvrstava u nekom razdoblju po učestalosti } \\
\text { pretraživanja od } 0 \text { do } 100 \text {, gdje } 100 \text { znači najveći broj pretraga } \\
\text { u tom razdoblju. }\end{array}$ & Google Trends (2021.) \\
\hline Pandemija & $\begin{array}{l}\text { Indeks učestalosti pretraživanja riječi Pandemija pokazuje broj } \\
\text { pretraživanja u Google tražilici, što pokazuje interes za ovom } \\
\text { temom a Google ih razvrstava u nekom razdoblju po učestalosti } \\
\text { pretraživanja od } 0 \text { do } 100 \text {, gdje } 100 \text { znači najveći broj pretraga } \\
\text { u tom razdoblju. }\end{array}$ & Google Trends (2021.) \\
\hline Lockdown & $\begin{array}{l}\text { Indeks učestalosti pretraživanja riječi Lockdown pokazuje broj } \\
\text { pretraživanja u Google tražilici, što pokazuje interes za ovom } \\
\text { temom a Google in razvrstava u nekom razdoblju po učestalosti } \\
\text { pretraživanja od } 0 \text { do } 100 \text {, gdje } 100 \text { znači najveći broj pretraga } \\
\text { u tom razdoblju. }\end{array}$ & Google Trends (2021.) \\
\hline
\end{tabular}

Izvor: izrada autora.

Prije provedbe korelacijske analize, nužno je proučiti kretanje odabranih indeksa. Slika 1. prikazuje promjene vrijednosti šest burzovnih indeksa, iz čega se jasno iščitava značaj početka pandemije za tržišta.

Na prvom Slikau Slike 1. prikazano je kretanje Dow Jones indeksa koji je u samo 29 dana trgovanja izgubio 37 \% vrijednosti, što je jedan od najbržih padova u povijesti. Indeksu je za oporavak bilo potrebno čak 172 dana trgovanja, da bi do kraja godine prvi put prešao granicu od 30.000 dolara, a treći kvartal 2021. godine završava s vrijednošću 34.391. S\&P500 pokazao je veću sposobnost oporavka od DJIA30. Unatoč tome što je u samo 24 dana trgovanja pao za čak 34 \%, s dotadašnjeg vrhunca od 3.386 19. veljače na 2.237 dolara 23. ožujka, trebalo mu je manje od pola godine 
Slika 1. Kretanje odabranih burzovnih indeksa

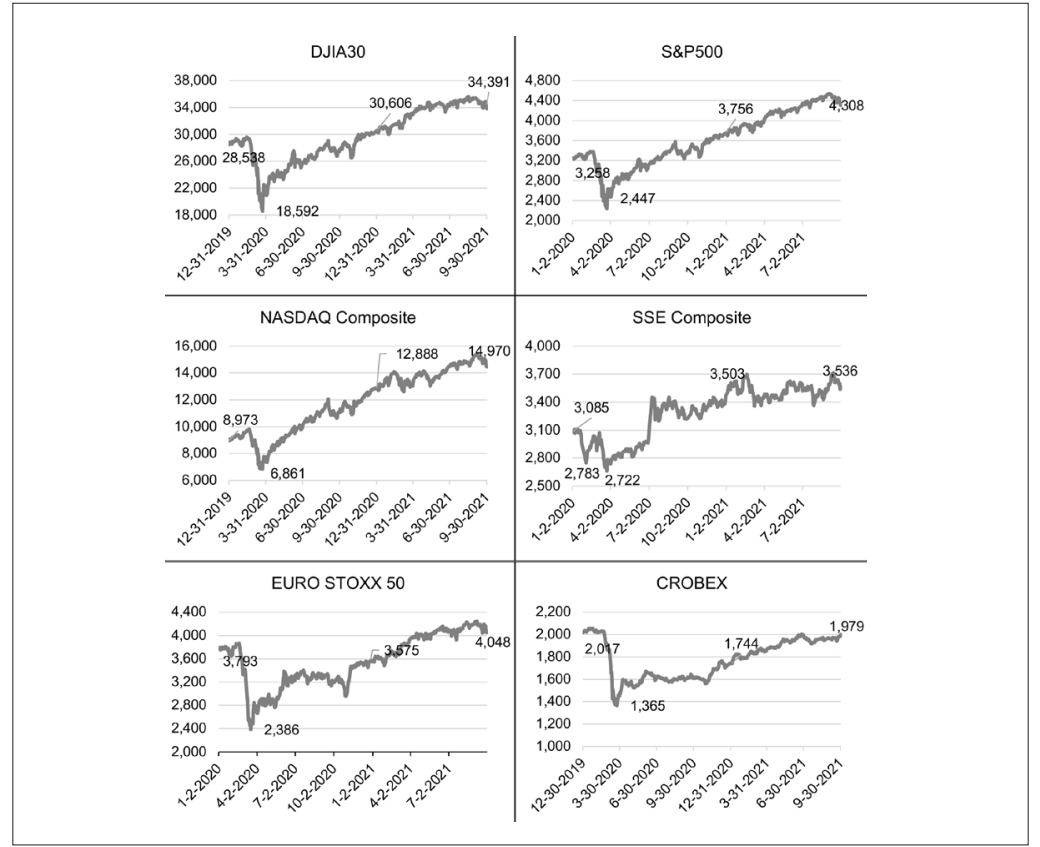

Izvor: NASDAQ (2021.), S\&P Global (2021.), Wall Street Journal (2021.), Yahoo Finance (2021.), Zagrebačka burza (2021.)

za povratak na nekadašnje razine. Takva razina volatilnosti u iznimno kratkom razdoblju nije zabilježena od sloma 1987. godine. Usporedbe radi, u globalnoj financijskoj krizi 2009. godine, indeksu S\&P500 je trebalo više od 350 trgovinskih dana da s vrhunca od 1.556 dolara dosegne dno od 667 dolara, dok se do novog rekorda čekalo 1.030 dana trgovanja. Treći indeks američkog tržišta najmanje je bio pod utjecajem pandemije. Bez obzira na to što je indeks do kraja prvog kvartala 2020. godine pao $24 \%$, daljnji rast je bio neviđen - čak $88 \%$ u tri kvartala. Indeks NASDAQ se brzo vraća na prijašnje razine, i to nakon 54 dana trgovanja. Pritom je indeks oborio vlastite rekorde prelazeći vrijednosti od $10.000,11.000$ te 12.000 dolara prvi put u povijesti.

U 2020.je godini SSE Composite indeks narastao za $13 \%$, što predstavlja skoro 1.000 postotnih bodova slabiji rezultat nego u 2019. godini. Reakcija indeksa SSE Composite na širenje koronavirusa vidljiva je dvaput: jednom u siječnju 2020. kad se virus proširio po Kini, gdje je pad iznosio 11,3 \%, dok je drugi put kada dolazi do globalnog širenja pandemije, zbog čega su velike svjetske burze krahirale te je indeks pao za 13,4\%. Međutim, kako je Kina pravodobnim intervencijama spriječila daljnje širenje virusa i zatvaranje gospodarstva, indeks je kraj 2020. godine dočekao u plusu na 3.503, a krajem trećeg kvartala 2021. godine nalazi se na otprilike jednakoj vrijednosti. Europski EURO STOXX 50 te hrvatski CROBEX bilježili su kretanja sličnija američkom tržištu. EURO STOXX 50 je u 2020. godine pao za 184 eura ili gotovo 5 \%, što čini znatno lošiji rezultat od kineskog i američkih indeksa. Sredinom veljače 2020 . godine, indeks je ostvario najbolje rezultate u proteklih 10 godina te je dostigao 3.865 eura, iznos koji nije viđen još od pretkrizne 2008. godine. Potom je nakon samo 21 dana izgubio čak 38 \% vrijednosti. Slično, CROBEX je kao i EURO STOXX 50 iskusio velik pad no nije
Anđelinović, M., Pavković, A., Šegović, B.

Utjecaj pandemije COVID-19 na burzovne indekse odabranih zemalja 
Anđelinović, M., Pavković, A., Šegović, B.

Utjecaj pandemije COVID-19 na burzovne indekse odabranih zemalja ga nadoknadio kao što su uspjeli američki burzovni indeksi u ostatku 2020. godine, dok u 2021. godini nastavljaju sporo rasti. Jasno je kako su indeksi u Europskoj uniji mnogo osjetljiviji i manje robusni od indeksa u SAD-u, no točnu jačinu korelacije između varijabli povezanih $s$ panedmijom i vrijednosti indeksa treba utvrditi korelacijskom analizom. Ona se provodi u idućem poglavlju.

\section{Rezultati empirijske analize}

Korelacijska analiza provodi se četiri tržišta: američko, kinesko, europsko te hrvatsko. Ovisno o razini na kojoj se iskazuju varijable s kojima se uspoređuju, koriste se dnevni ili tjedni podaci o kretanju burzovnih indeksa.

\subsection{Utjecaj najznačajnijih varijabli na kretanje indeksa na američkom tržištu}

Dow Jones Industrial Average 30 imao je najjaču reakciju na korona krizu od tri analizirana američka burzovna indeksa. Uz to što je zabilježio najveći pad vrijednosti,ovom indeksu trebalo je i najviše dana za povratak na razine prije krize. Koeficijenti korelacije DJIA30 na razini 2020. godine su jače negativni nego kod ostalih indeksa, a situacija je slična i u analiziranom razdoblju 2021. godine. U drugom kvartalu 2020. godine slabije korelacije govore 0 sporijem oporavljanju indeksa, jer je usporedno s padom učestalosti pretraživanja ključnih riječi i pada broja zaraženih i umrlih osoba, DJIA30 indeks rastao sporije od ostalih. Razlog ovakvom kretanju analiziranog DJIA30 indeksa može se pronaći u njegovoj strukturi u kojoj prevladavaju tradicionalno industrijske kompanije, kao što sam naziv indeksa sugerira. U vrijeme pandemije uzrokovane koronavirusom, gospodarstva svih zemalja, a posebno gospodarstvo SAD-a kao globalnog gospodarskog lidera, se transformiralo prema digitalnoj sferi, te su dionice kompanija koje se bave digitalnom transformacijom, softverskim rješenjima, umjetnom inteligencijom, podrškom radu na daljinu i sl., doživjele najveći rast. Taj rast nije se reflektirao na rast DJIA30 indeksa iz jednostavnog razloga što dionice tih i takvih kompanija nisu sastavni dio analiziranog indeksa. Tablica 2. prikazuje korelacije DJIA30 indeksa na tjednoj bazi.

U Tablici 2.može se uočiti jaka negativna korelacija kod četiri od prikazanih šest varijabli u 2020. godini, dok broj novozaraženih i umrlih imaju umjereno jaku i slabu pozitivnu korelaciju. lako je rast broja novonezaposlenih uslijedio tek nakon pada vrijednosti indeksa, negativna korelacija stoji zbog trenda prisutnog u ostatku godine kada je indeks rastao, a broj novonezaposlenih padao. Započinjanje novog vala u drugom dijelu 2020. godine, što je značilo i veći broj novozaraženih i umrlih, nije utjecalo na indeks, iz čega se vidi otpornost i stabilnost tržišta unatoč kriznoj situaciji u gospodarstvu. Unatoč tome što su korelacije u prosjeku najjače u prvom kvartalu, jače su veze uspostavljene unutar 30 dana trgovanja od pojave virusa u SAD-u. No, iako dotad epidemija nije bila uzela maha, očito je sama pojava virusa i jedan smrtni slučaj bio dovoljan za početak jednog od najvećih padova indeksa u povijesti trgovanja burze. Ali, bez obzira što je pandemijska opasnost još uvijek izražena, utjecaj na gospodarstvo i kretanje DJIA30 indeksa slabi. Objašnjenje se može naći u činjenici da su dionici tržišta svoja negativna očekivanja već konzumirali i ugradili u pad cijena u prvom kvartalu 2020. godine. Može se dodati i laičko objašnjenje da su se dionici tržišta nakon početnog šoka, "naučili živjeti“ s pandemijom i pripadajućim rizicima. Svemu tome, kod analize robusnosti rasta svih burzovnih indeksa u SAD-u

Tablica 2. Korelacija DJIA30 indeksa i broja novonezaposlenih, novozaraženih, umrlih, te ključnih riječi na tjednoj bazi

\begin{tabular}{|l|l|l|l|l|}
\hline \multicolumn{1}{|c|}{ Tjedna promjena } & \multicolumn{2}{c|}{01} & $\mathbf{0 2}$ & 2021 \\
\hline Tjedni broj novozaraženih & 0,486 & $-0,606$ & $-0,023$ & $-0,395$ \\
\hline Tjedni broj umrlih & 0,053 & $-0,565$ & $-0,528$ & $-0,788$ \\
\hline Tjedni broj novonezaposlenih & $-0,605$ & $-0,459$ & $-0,783$ & $-0,718$ \\
\hline Koronavirus & $-0,735$ & $-0,858$ & $-0,788$ & $-0,888$ \\
\hline Pandemija & $-0,689$ & $-0,707$ & $-0,913$ & $-0,176$ \\
\hline Lockdown & $-0,560$ & $-0,832$ & $-0,803$ & $-0,921$ \\
\hline
\end{tabular}

Izvor: izračun autora prema podacima S\&P Global (2021.), Google Trends (2021.), Federal Reserve Economic Data (2021.) i Our World in Data (2021.). 
Tablica 3. Korelacija S\&P500 indeksa i broja novonezaposlenih, novozaraženih, umrlih te ključnih riječi na tjednoj bazi

\begin{tabular}{|l|l|l|l|l|}
\hline \multicolumn{1}{|c|}{ Tjedna promjena } & \multicolumn{2}{c|}{$\mathbf{0 1}$. } & \multicolumn{2}{c|}{$\mathbf{2 0 2 1}$} \\
\hline Tjedni broj novozaraženih & 0,637 & $-0,612$ & $-0,374$ & $-0,217$ \\
\hline Tjedni broj umrlih & 0,213 & $-0,571$ & $-0,507$ & $-0,632$ \\
\hline Tjedni broj novonezaposlenih & $-0,551$ & $-0,466$ & $-0,839$ & $-0,942$ \\
\hline Koronavirus & $-0,760$ & $-0,855$ & $-0,857$ & $-0,692$ \\
\hline Pandemija & $-0,668$ & $-0,705$ & $-0,934$ & $-0,895$ \\
\hline Lockdown & $-0,531$ & $-0,829$ & $-0,814$ & $-0,115$ \\
\hline
\end{tabular}

Izvor: izračun autora prema podacima S\&P Global (2021.), Google Trends (2021.), Federal Reserve Economic Data (2021.) i Our World in Data (2021.).

Tablica 4. Korelacija NASDAQ Composite indeksa i broja novonezaposlenih, novozaraženih, umrlih te ključnih riječi na tjednoj bazi

\begin{tabular}{|l|l|l|l|l|}
\hline \multicolumn{1}{|c|}{ Tjedna promjena } & \multicolumn{2}{c|}{$\mathbf{0 1}$} & $\mathbf{0 2}$ & 2021. \\
\hline Tjedni broj novozaraženih & 0,772 & $-0,599$ & 0,127 & $-0,021$ \\
\hline Tjedni broj umrlih & 0,401 & $-0,558$ & $-0,684$ & $-0,371$ \\
\hline Tjedni broj novonezaposlenih & $-0,414$ & $-0,453$ & $-0,933$ & $-0,808$ \\
\hline Koronavirus & $-0,696$ & $-0,838$ & $-0,880$ & $-0,558$ \\
\hline Pandemija & $-0,551$ & $-0,685$ & $-0,930$ & $-0,776$ \\
\hline Lockdown & $-0,425$ & $-0,827$ & $-0,889$ & $-0,063$ \\
\hline
\end{tabular}

Izvor: izračun autora prema podacima S\&P Global (2021.), Google Trends (2021.), Federal Reserve Economic Data (2021.) i Our World in Data (2021.).

može se dodati i zadržavanje iznimno ekspanzivnih monetarnih politika od strane središnje banke FED. Tablica 3. prikazuje utjecaj varijabli na S\&P500.

Najsnažnija negativna korelacija u 2020. godini vidljiva je kod riječi Koronavirus $(-0,760)$. Ona je jaka u svakom promatranom razdoblju, a posebice u drugom tromjesečju kada je učestalost pretraživanja te riječi pala, a indeks je rastao. Korelacije su kod ovog indeksa u prosjeku najjače u drugom kvartalu. Bez obzira što je ovaj rezultat možda neobičan, to se može pripisati trendu pada broja zaraženih, umrlih i nezaposlenih kao i učestalosti pretraživanja ključnih riječi, dok se $u$ isto vrijeme indeks oporavljao od pada na kraju prvog kvartala. U 2021. godini interesantne su jake negativne korelacije $s$ tjednim brojem novonezaposlenih i pretraživanjem riječi Pandemija, po čemu ovaj indeks ne pokazuje sličnosti s DJIA30. Tablica 4. daje pregled korelacija sa zadnjim američkim indeksom, NASDAO Composite.

Vrijednosti u Tablici 4. još jednom potvrđuju veću otpornost indeksa NASDAQ na pandemiju od ostalih američkih indeksa. U cijelom analiziranom razdoblju, pa čak i u prvom kvartalu 2020. godine, ovaj je indeks imao mnogo slabiju negativnu korelaciju i jaču pozitivnu, dok je $s$ rastom broja novonezaposlenih i padom pretraživanja ključnih riječi u drugom kvartalu 2020. godine indeks brže rastao od drugih indeksa. Kako pokazuje Tablica 4. koeficijenti korelacije slabe u 2021. godini za sve prikazane varijable.

Kako je prethodno rečeno, širenje virusa imalo je za posljedicu zatvaranje poduzeća i gospodarstva, rast nezaposlenosti te značajan pad bruto domaćeg proizvoda. Tablica 5. prikazuje odnose preostalih varijabli s američkim indeksima. Kretanje razlike između stvarnog i očekivanog BDP-a te stvarnih i očekivanih kamatnih stopa prikazano je samo za 2020. godinu, dok se pojavom cjepiva u 2021. otvorila mogućnost za analizu korelacije broja cijepljenih i indeksa.

U Tablici 5. može se vidjeti kako su na dnevni koeficijenti korelacije razlike BDP-a s promjenom indeksa DJIA30 i NASDAO negativni pa je pri neočekivanom rastu BDP-a zabilježen pad vrijednosti indeksa i obratno, dok je za S\&P500 primjetna pozitivna korelacija. Zbog nelogičnosti prisutne kod ovih koeficijenata treba proučiti promjenu indeksa u sljedećem 5-dnevnom razdoblju trgovanja. U tom je slučaju očita jaka
Anđelinović, M., Pavković, A., Šegović, B.

Utjecaj pandemije COVID-19 na burzovne indekse odabranih zemalja 
Anđelinović, M., Pavković, A., Šegović, B.

Utjecaj pandemije COVID-19 na burzovne indekse odabranih zemalja

Tablica 5. Korelacija američkih indeksa i razlike stvarnog i očekivanog BDP-a SAD-a, razlike stvarnih i očekivanih kamatnih stopa te broja cijepljenih osoba

\begin{tabular}{|c|c|c|c|}
\hline \multicolumn{4}{|c|}{ Korelacije s razlikom stvarnog i očekivanog BDP-a SAD-a } \\
\hline Dnevna promjena SP500 & 0,522 & 5-dnevna promjena SP500 & 0,754 \\
\hline Dnevna promjena DJIA30 & $-0,286$ & 5-dnevna promjena DIIA30 & 0,787 \\
\hline Dnevna promjena NASDAQ & $-0,218$ & 5-dnevna promjena NASDAQ & 0,663 \\
\hline \multicolumn{4}{|c|}{ Korelacjes s razlikom stvarnih i očekivanih kamatnih stopa FED-a } \\
\hline Dnevna promjena SP500 & 0,664 & 5-dnevna promjena SP500 & 0,473 \\
\hline Dnevna promjena DJIA30 & 0,648 & 5-dnevna promjena DJIA30 & 0,563 \\
\hline Dnevna promjena NASDAQ & 0,710 & 5-dnevna promjena NASDAQ & 0,266 \\
\hline \multicolumn{2}{|c|}{ Korelacije s brojem cijepljenih osoba } & & \\
\hline Dnevna promjena SP500 & $-0,480$ & & \\
\hline Dnevna promjena DJIA30 & $-0,299$ & & \\
\hline Dnevna promjena NASDAQ & $-0,582$ & & \\
\hline
\end{tabular}

Izvor: izračun autora prema podacima S\&P Global (2021.), Google Trends (2021.), Federal Reserve Economic Data (2021.) i Our World in Data (2021.).

Slika 2. Američki burzovni indeksi, pokazatelji pandemije i pretraživanje ključnih riječi

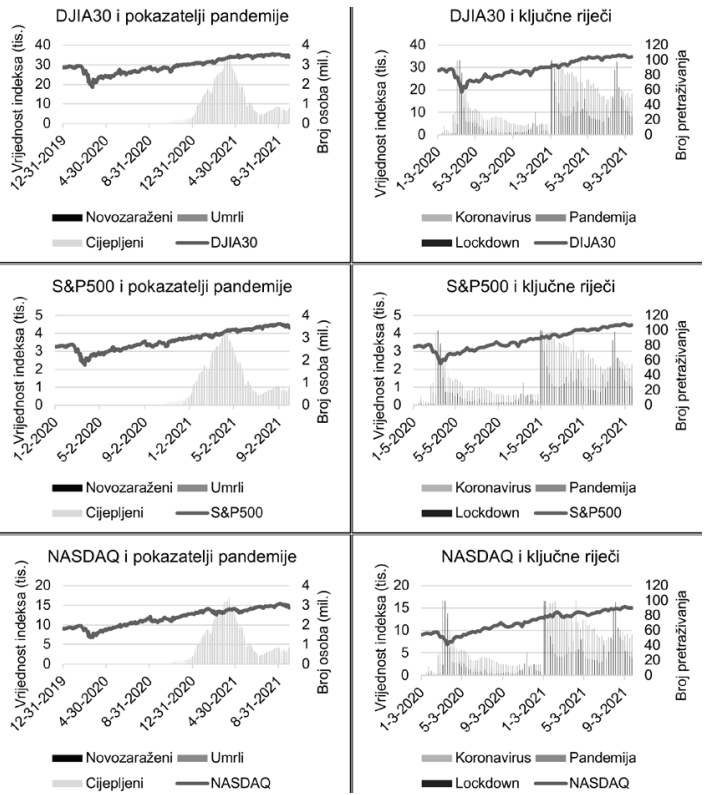

Izvor: izrada autora prema podacima Google Trends (2021.), NASDAO (2021.), Our World in Data (2021.), S\&P Global (2021.) i Wall Street Journal (2021.).

korelacija kod svih američkih indeksa, s najvećom kod DJIA30 i pokazuje da je na razini 2020. godine činjenica da je stvarni BDP-a bio veći od očekivanog utjecala na tržišta. Vrijedi i obratno. Što se tiče kamatnih stopa, vidi se da pad kamatnih stopa koji je bio veći od očekivanog nije značajno utjecao na 
tržišta u kratkom roku. Štoviše, snažne korelacije na dnevnim razinama govore da je u slučaju kada je FED snižavao kamatne stope bio vidljiv veliki pad tržišta. No, bitno je napomenuti kako je FED spuštao kamatne stope u dva navrata nakon nenajavljenih sjednica te je ostatak godine te kamatne stope držao na $0,25 \%$. Teško je reći koliko su njegove akcije potakle smirivanje tržišta, ali se ne može se zaključiti kako FED nije iskoristio instrumente monetarne politike za poboljšanje stanja. Konačno, kod broja cijepljenih primjetne su negativne, ali slabe korelacije s kretanjem indeksa. Općenito, u 2021. godini je oslabljen učinak varijabli pandemije na indekse pa ni broj cijepljenih nema veći učinak, što pokazuje i Slika 2.

Zaključci korelacijske analize za SAD potvrđuju se grafovima na Slici 2. Varijable koje pokazuju kretanje pandemije i indeksi učestalosti pretraživanja ključnih riječi Koronavirus, Pandemija i Lockdown bili su značajni jedino krajem prvog kvartala 2020. godine, kada je došlo do globalnog širenja virusa, a u kasnijim razdobljima učinak nije toliko vidljiv. Za razliku od SAD-a i ostatka svijeta, kinesko je gospodarstvo ranije pogođeno pandemijom, što se očitovalo u ranijem padu njihovog tržišta. U nastavku se proučava odnos istih varijabli za Kinu.

\subsection{Utjecaj najznačajnijih varijabli na kretanje indeksa na kineskom tržištu}

Indeks Shanghai Stock Exchange Composite prvi je reagirao na izbijanje pandemije COVID-19. Kao najrelevantniji indeks kineskih tržišta kapitala, SSE je već krajem siječnja 2020. pao ispod 3.000 juana, a taj pad bi možda bio i izraženiji da vlada nije zaustavila trgovanje od 23. siječnja do 3 . veljače 2020. godine. U Kini su prvi slučajevi zaraze zabilježeni još potkraj 2019. godine, a do kraja siječnja 2020. bilo je registrirano već oko 10.000 oboljelih osoba. Kada su se burze ponovno otvorile, SSE Composite indeks imao je gubitak od $7,7 \%$ vrijednosti zadnjeg dana trgovanja, ali otad počinje rasti usprkos velikim brojevima zaraženih i umrlih osoba. Daljnje povećanje vrijednosti indeksa sprječava širenje koronavirusa globalno što je uzrokovalo pad na svim tržištima, pa tako i na šangajskom. Tablica 6. daje pregled korelacija za SSE Composite indeks.

U 2020. godini može se vidjeti umjerena negativna korelacija tjednog broja zaraženih i umrlih osoba te pretraživanja ključnih riječi $s$ kretanjem SSE Composite indeksa. Najsnažnije korelacije očituju se u drugom kvartalu 2020. godine, kada padaju pretraživanja weba i broj zaraženih i umrlih osoba, što se veže uz rast indeksa. $S$ druge strane, u 2021. godini promatrane varijable pokazuju se neznačajnim za indeks. Važno je naglasiti određene rezerve prema rezultatima analize SSE Composite indeksa, prvenstveno zbog upitnog broja registriranih slučajeva zaraze od strane njihove vlade, zbog mjera koje je vlada upotrijebila kako bi spriječila rasprodaju na burzama i kako bi očuvala financijsku stabilnost, ali i zbog upitne slobode i transparentnosti pretraživanja pojedinih pojmova.

Tablica 6. Korelacija SSE Composite indeksa i broja novozaraženih, umrlih te ključnih riječi na tjednoj bazi

\begin{tabular}{|c|c|c|c|c|}
\hline Tjedna promjena & 2020. & 01 & 02 & 2021. \\
\hline Tjedni broj novozaraženih & $-0,235$ & $-0,144$ & $-0,261$ & 0,218 \\
\hline Tjedni broj umrlih & $-0,334$ & $-0,093$ & $-0,151$ & 0,100 \\
\hline Koronavirus & $-0,557$ & $-0,262$ & $-0,707$ & 0,106 \\
\hline Pandemija & $-0,391$ & 0,012 & $-0,313$ & $-0,107$ \\
\hline Lockdown & $-0,501$ & $-0,663$ & $-0,494$ & $-0,300$ \\
\hline
\end{tabular}

Izvor: izračun autora prema podacima Yahoo Finance (2021.), Google Trends (2021.) i Our World in Data (2021.).

Tablica 7. Korelacija SSE indeksa i razlike stvarnog i očekivanog BDP-a te broja cijepljenih osoba

\begin{tabular}{|c|c|c|c|}
\hline \multicolumn{4}{|c|}{ Korelacije s razlikom stvarnog i očekivanog BDP-a } \\
\hline Dnevna promjena SSE & $-0,877$ & 5-dnevna promjena SSE & $-0,080$ \\
\hline \multicolumn{2}{|c|}{ Korelacija s brojem cijepljenih osoba } & & \\
\hline Dnevna promjena SSE & 0,027 & & \\
\hline
\end{tabular}

Izvor: izračun autora prema podacima Yahoo Finance (2021.), Investing.com (2021.) i Our World in Data (2021.). 
Anđelinović, M., Pavković, A., Šegović, B.

Utjecaj pandemije COVID-19 na burzovne indekse odabranih zemalja

Slika 3. SSE Composite i pokazatelji pandemije i pretraživanje ključnih riječi
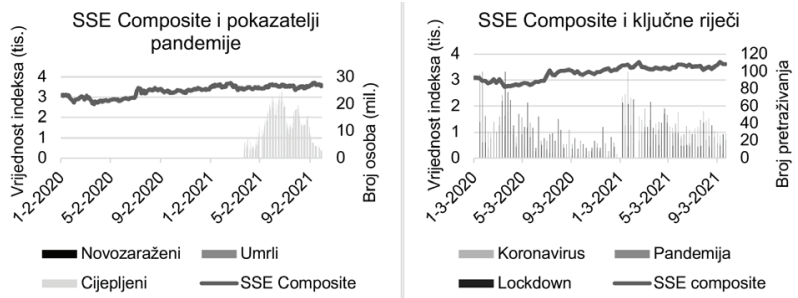

Izvor: izrada autora prema podacima Google Trends (2021.), Our World in Data (2021.) i Yahoo Finance (2021.).

Prije analize rezultata korelacije između SSE Composite indeksa i razlike stvarnog i očekivanog bruto domaćeg proizvoda, treba naglasiti kako se radi o malom uzorku sa samo tri objave. U 2020. godini od tri službena rezultata o veličini kineskog BDP-a, dva su rezultata bolja od očekivanog, a jedan lošiji.Uz podatke o BDP-u, prikazuje se veza s brojem cijepljenih osoba u 2021. godini.

U Tablici 7. prisutna je iznimno jaka negativna korelacija s dnevnim promjenama indeksa, kao i posebno slaba korelacija s 5-dnevnim promjenama. Ovaj neočekivani rezultat treba promatrati $s$ dozom opreza zbog malog uzorka, ali i moguće netransparentnosti kineske vlade 0 stvarnoj veličini kineskog bruto domaćeg proizvoda. Za razliku od korelacije s brojem cijepljenih u SAD-u, u Kini se vidi pozitivna, ali iznimno slaba veza, a učinak cijepljenja bio je izražen jedino u svibnju 2021. godine.

Slika 3. pokazuje da je kineski indeks bio nešto manje volatilan od američkih. Najveći broj pretraživanja riječi Koronavirus i Pandemija zabilježen je u četvrtom tjednu 2020. godine, odnosno u onom tjednu kada je krenuo pad vrijednosti indeksa, dok je riječ Lockdown najčešće pretraživana u dvanaestom tjednu 2020. godine. Razlog zašto je ovaj podatak zanimljiv je što je $\mathrm{u}$ tom tjednu krenuo lockdown u najvećem broju zemalja u svijetu, ali ne i u Kini. Naime, tamo je zatvaranje gospodarstva počelo već krajem siječnja 2020. godine, ali je upravo u 12. tjednu godine većina svjetskih burzi krahirala prije negoli su krenule u trend rasta. U 2021. godini, najveći broj pretraživanja zabilježen je u siječnju, a otad kreće padati.

\subsection{Utjecaj najznačajnijih varijabli na kretanje indeksa na europskom i hrvatskom tržištu}

Posljednja analiza odnosi se na europsko i hrvatsko tržište. EURO STOXX 50 je kao najveći europski burzovni indeks, imao ponešto drukčiju reakciju na pandemiju od kineskog i američkih indeksa. Nakon iznimnog pada u ožujku 2020. godine, EURO STOXX 50 nije se uspio vratiti na ranije razine poput ostalih indeksa, nego je do kraja 2020. godine ostvarivao polagan rast koji je graničio sa stagnacijom. Ipak, u jednom je pogledu sličan ostalim proučenim indeksima, a to je da je njegov pad uzrokovan pojavom straha od širenja

Tablica 8. Korelacija EURO STOXX 50 indeksa i broja novozaraženih, umrlih te ključnih riječi na tjednoj bazi

\begin{tabular}{|l|l|l|l|l|}
\multicolumn{1}{c}{ Tjedna promjena } & \multicolumn{2}{c|}{2020.} & 02 & 02 \\
\hline Tjedni broj novozaraženih & 0,073 & $-0,741$ & $-0,601$ & $-0,784$ \\
\hline Tjedni broj umrlih & $-0,160$ & $-0,672$ & $-0,714$ & $-0,840$ \\
\hline Koronavirus & $-0,778$ & $-0,989$ & $-0,758$ & $-0,632$ \\
\hline Pandemija & $-0,627$ & $-0,933$ & $-0,775$ & $-0,868$ \\
\hline Lockdown & $-0,295$ & $-0,806$ & $-0,808$ & $-0,792$ \\
\hline
\end{tabular}

Izvor: izračun autora prema podacima Yahoo Finance (2021.), Google Trends (2021.) i Our World in Data (2021.). 
Tablica 9. Korelacija indeksa CROBEX i broja novozaraženih, umrlih te ključnih riječi na tjednoj bazi

\begin{tabular}{|l|l|l|l|l|}
\hline \multicolumn{1}{|c|}{ Tjedna promjena } & \multicolumn{2}{c|}{$\mathbf{0 1}$} & $\mathbf{0 2}$ & 2021. \\
\hline Tjedni broj novozaraženih & $-0,022$ & $-0,719$ & $-0,528$ & $-0,198$ \\
\hline Tjedni broj umrlih & 0,027 & $-0,639$ & $-0,604$ & $-0,530$ \\
\hline Koronavirus & $-0,466$ & $-0,887$ & $-0,453$ & $-0,225$ \\
\hline Pandemija & $-0,181$ & $-0,633$ & $-0,569$ & $-0,369$ \\
\hline Lockdown & $-0,110$ & $-0,402$ & 0,371 & $-0,392$ \\
\hline
\end{tabular}

Izvor: izračun autora prema podacima Zagrebačke burze (2021.), Google Trends (2021.) i Our World in Data (2021.).

virusa, a ne samim širenjem virusa. Naime, do 19. veljače (dan od kojeg je indeks krenuo padati) virus je inficirao tek 19 osoba u čitavoj Europskoj uniji. Vrijednost indeksa počela se oporavljati puno ranije nego se koronavirus više proširio Europom. Interesantno je i to da je EURO STOXX 50 reagirao na novi val epidemije u zadnjem tromjesečju 2020. godine, kad je uslijed još većeg broja novozaraženih i umrlih ponovno pao, ali manje nego ranije. Tablica 8. prikazuje korelacije EURO STOXX 50 s odabranim varijablama.

U Tablici 8. primjetne su snažne korelacije između vrijednosti burzovnog indeksa Eurozone i pretraživanja ključnih riječi na tjednoj razini. Korelacije su prosječno najjače u prvom kvartalu 2020. godine, pri čemu su uočene jače negativne veze. Rezultati na tjednoj razini su kompatibilni s onima za američke indekse, uz manje odstupanje kod varijable Lockdown. Budući da je ova varijabla najveću vrijednost postigla tek krajem 2020.godine, vidi se da ona na godišnjoj razini nema značajnu vezu s indeksom. Na temelju analize zaključuje se kako EURO STOXX 50 i varijable pandemije imaju jake korelacije u promatranim razdobljima, ali to ne znači da je rast ovih varijabli uzrokovao pad vrijednosti indeksa.Za takav zaključak bila bi nužna šira analiza determinanti kretanja indeksa.Suprotno od Kine u kojoj veza $s$ analiziranim varijablama slabi, u Europi neke varijable imaju jači negativan učinak u 2021. godini nego u 2020. godini, što je slučaj i u SAD-u. Primjerice, posebno je visoka negativna korelacija indeksa s pretraživanjem riječi Pandemija koja iznosi gotovo -0,9, dok su snažno negativni i preostali koeficijenti korelacije.

Što se tiče Republike Hrvatske, kretanje CROBEX-a najsličnije je kretanju indeksa Eurozone, zbog čega se Hrvatska i prikazuje usporedno s europskim tržištem. CROBEX se nije oporavio od gubitaka uzorkovanih pandemijom pa do kraja trećeg kvartala 2021. godine ne dostiže pred-pandemijske vrijednosti. Prema prikazanom rezultatu, ovaj je indeks manje robustan od svih drugih indeksa koji se proučavaju, a razlozi za to mogu se pronaći uglavnom izvan utjecaja pandemije i s njom povezanih varijabli. Tablica 9. daje pregled korelacija za CROBEX.

Tablica 9. pokazuje da korelacija praktički ne postoji na razini čitave 2020. godine, ali je bila jaka veza kod varijabli Koronavirus i broj novozaraženih u prvom kvartalu 2020. godine. U drugom kvartalu 2020. godine korelacije za navedene varijable se smanjuju,dok varijabla Lockdown zauzima pozitivan predznak, što rezultira slabim i nejasnim vezama na godišnjoj razini. U 2021. godini srednje je jaka negativna veza između CROBEX-a i broja umrlih, dok su koeficijenti kod ostalih varijabli slabije negativni. U Tablici 10. uspoređuju se korelacije europskog i hrvatskog indeksa s podacima o BDP-u i brojem cijepljenih osoba.

Tablica 10. Korelacija europskog i hrvatskog indeksa i razlike stvarnog i očekivanog BDP-a te broja cijepljenih osoba

\begin{tabular}{|l|l|l|c|}
\hline \multicolumn{5}{|c|}{ Korelacije s razlikom stvarnog i očekivanog BDP-a } & 0,611 \\
\hline Dnevna promjena EURO STOXX 50 & 0,354 & 5-dnevna promjena EURO STOXX 50 & 0,444 \\
\hline Dnevna promjena CROBEX & $-0,211$ & 5-dnevna promjena CROBEX & \\
\hline \multicolumn{1}{|c|}{ Korelacije s brojem cijepljenih osoba } & \\
\hline Dnevna promjena EURO STOXX 50 & 0,633 & \\
\hline Dnevna promjena CROBEX & 0,367 &
\end{tabular}

Izvor: izračun autora prema podacima Investing.com (2021.), Yahoo Finance (2021.), Our World in Data (2021.) i Zagrebačke burze (2021.). 
Anđelinović, M., Pavković, A., Šegović, B.

Utjecaj pandemije COVID-19 na burzovne indekse odabranih zemalja

Slika 4. EURO STOXX 50 i CROBEX i pokazatelji pandemije i pretraživanje ključnih riječi

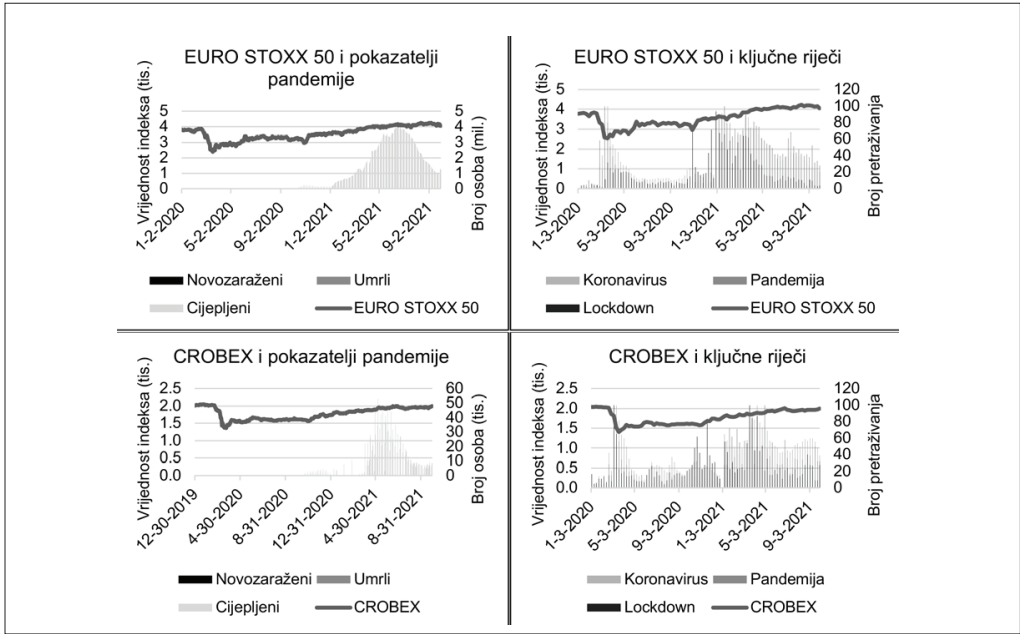

Izvor: izrada autora prema podacima Google Trends (2021.), Our World in Data (2021.), Yahoo Finance (2021.) i Zagrebačke burze (2021.).

Slično kao i kod podataka za SAD, službeno su objavljeni podaci 0 bruto domaćem proizvodu Europske unije za prva tri kvartala i za svaki kvartal triput. Na temelju devet objavljenih izvješća donose se gotovo isti zaključci kao i za američke indekse, odnosno da je u prvom danu trgovanja indeks bilježio manju pozitivnu korelaciju s razlikom očekivane i ostvarene stope rasta BDP-a nego u 5-dnevnom razdoblju. U hrvatskom slučaju, vidi se slaba negativna veza na dnevnoj te umjereno jaka pozitivna veza na 5 -dnevnoj razini. Kod bržeg rasta stvarnog BDP-a od očekivanog, u 2020. je godini u prvom danu trgovanja indeks izgubio na vrijednosti, ali je u idućim danima ostvarivao rast i obrnuto. Negativna korelacija pri dnevnoj promjeni indeksa može biti nejasna, ali treba istaknuti ponovno kako se radi o malom uzorku koji vjerojatno ne pokazuje pravu vezu između ove dvije varijable. Govoreći o cijepljenju, najjači utjecaj na indekse vidljiv je upravo u Europskoj uniji koje je jedino među promatranim tržištima sa srednje jakim pozitivnim koeficijentom korelacije. U Hrvatskoj je učinak također pozitivan, ali manje izražen. Jačina korelacija u različitim razdobljima može se iščitati i sa Slike 4.
Kako je već pokazano u Tablici 8., za europsko tržište se može reći da je pod najvećim utjecajem varijabli pandemije. Kod pretraživanja riječi vezanih uz pandemiju treba istaknuti da Google ne vodi takvu statistiku na razini cijele Europske unije pa se koriste prosjeci pretraživanja tih riječi za Francusku i Njemačku jer skoro 70 \% poduzeća u EURO STOXX 50 indeksu dolazi iz te dvije zemlje. Veći broj pretraživanja ključnih riječi nije uvijek prethodio padu tržišta. Dapače, indeks pretraživanja riječi Koronavirus i Pandemija ostvario je najveću vrijednost u 11. i 12. tjednu kada je EURO STOXX 50 bio na najnižim razinama u godini. Interesantno je kako je pretraživanje riječi Lockdown bilo češće u zadnjem kvartalu 2020. godine, i to u vrijeme kad je on uveden u Francuskoj i Njemačkoj. Iz Slike 4. jasno je kako CROBEX pokazuje iznimno visoku korelaciju s indeksom EURO STOXX 50 koja iznosi čak 0,914, ali CROBEX nije toliko reagirao na brojeve novozaraženih $\mathrm{i}$ umrlih, ali ni cijepljenih osoba. Burzovni indeks imao je jaču negativnu vezu s učestalosti pretraživanja jedino u ožujku 2020. godine, dok u ostalim razdobljima nije uočljiva značajna povezanost.

$\mathrm{Na}$ temelju provedene korelacijske analize 
može se donijeti nekoliko zaključaka o učinku pandemije na proučena tržišta. Zajednička odlika svih tržišta je najjača reakcija na pandemiju krajem prvog kvartala 2020. godine kada se pandemija proširila na globalnoj razini, što se vidi čak i kod kineskog tržišta unatoč tome što se virus ranije proširio u Kini. U SAD-u je zanimljivo da je broj novonezaposlenih važniiji faktor u 2021. godini, dok je jak i učinak pretraživanja nekih ključnih riječi te očekivanja BDP-a i kamatnih stopa. Na kineskom tržištu značajnom se pokazuje samo varijabla razlike stvarnog i očekivanog BDP-a koja ima jak negativan učinak na SSE Composite. Europsko tržište specifično je pod utjecajem broja cijepljenih osoba, što se ne vidi kod ostalih tržišta, dok hrvatsko tržište uvelike slijedi kretanja u Eurozoni, no ne pokazuje jednako jaku vezu s varijablama vezanim uz pandemiju.

Prije iznošenja zaključnih razmatranja, potrebno je navesti dva ograničenja istraživanja. Prvo ograničenje rada odnosi se na upotrijebljenu metodu. lako korelacijska analiza predstavlja jednostavnu metodu i daje korisne rezultate koje je lako interpretirati, nije metoda na temelju koje se dokazuje, primjerice, uzročnost, već se isključivo pokazuje postojanje veze. Drugo ograničenje čini broj varijabli koje su upotrijebljene u analizi. Naime, uključeno je desetak varijabli koje su važne za ovo područje, ali bi uključivanje većeg broja varijabli moglo dati uvid u neke nove aspekte ovog problema. Prema tome, preporuča se u budućim istraživanjima proširiti analizu novim varijablama i upotrebom različite metodologije kako bi se moglo odgovoriti na povezana istraživačka pitanja.

\section{Zaključak}

Pandemija je globalni fenomen koji je s vrlo malim vremenskim odmakom ugrozio zdravlje stanovništva, gospodarstava i tržišta kapitala svih analiziranih zemalja. Međutim, utjecaj pandemije na tržišta kapitala analiziranih zemalja, mjereno utjecajem odabranih varijabli na kretanje reprezentativnih burzovnih indeksa bilo je heterogeno. Najrobusnije kretanje burzovnih indeksa u analiziranom razdoblju odvija se u SAD-u i manifestira se u višestrukom obaranju povijesnih maksimuma istih. Ipak postoje razlike između tri analizirana indeksa u SAD-u. Najmanje robustan indeks je DJIA30. Razlog ovakvom kretanju analiziranog DJIA30 indeksa može se pronaći u njegovoj strukturi u kojoj prevladavaju tradicionalno industrijske kompanije. U vrijeme pandemije uzrokovane korona virusom, dionice kompanija koje se bave digitalnom transformacijom i srodnim područjima su doživjele najveći rast. Taj rast nije se reflektirao na rast DJIA30 indeksa iz jednostavnog razloga što dionice tih i takvih kompanija nisu sastavni dio analiziranog indeksa, ali se reflektirao na intenzivniji rast indeksa S\&P500 te NASDAQ. Korelacija s razlikom između stvarnog i očekivanog BDP-a je srednje jaka i pozitivna kod indeksa S\&P500, dok kod preostalih indeksa nije značajna. Nasuprot tome, kod kamatnih stopa očituje se jača pozitivna veza kod svih američkih indeksa. Kod kineskog tržišta uočavaju se drukčija kretanja indeksa nego u drugim analiziranim tržištima te različite veze s varijablama pandemije. Međutim, važno je naglasiti određene rezerve prema rezultatima analize SSE Composite, prvenstveno zbog upitnog broja registriranih slučajeva zaraze, zbog višednevnog prekida rada burze u prvom kvartalu 2020., ali i zbog upitne slobode i transparentnosti pretraživanja pojedinih pojmova. Prilikom analize dioničkog indeksa EURO STOXX 50, utvrđena je znatno manja robusnost u odnosu na dioničke indekse u SAD-u. Europsko tržište specifično je pod utjecajem broja cijepljenih osoba, što se ne vidi kod ostalih tržišta. Hrvatski dionički indeks CROBEX pokazuje najmanju robusnost od svih analiziranih indeksa. Daleko od svojih povijesnih maksimuma iz pretprošlog desetljeća, CROBEX vrlo sporo prati globalne trendove oporavka burzovnih indeksa nakon pandemije. Hrvatsko tržište uvelike slijedi kretanja u Eurozoni, no ne pokazuje jednako jaku vezu s varijablama vezanim uz pandemiju. Razloge za stagnaciju i ključeve oporavka hrvatskoga tržišta kapitala potrebno je pronaći u varijablama koje nisu vezane uz pandemiju te su, kao takve, ostale izvan dosega ovog istraživanja. Nadalje, uspoređujući rezultate analize u 2020. i 2021. godini, može se zaključiti da je na svim tržištima, do najintenzivnije reakcije burzovnog indeksa na pandemijske varijable došlo na samome početku pandemije dok su apsolutni brojevi novooboljelih i umrlih od posljedica COVID-19 bili na niskim razinama u apsolutnom smislu. Kako vrijeme odmiče, taj
Anđelinović, M., Pavković, A., Šegović, B.

Utjecaj pandemije COVID-19 na burzovne indekse odabranih zemalja 
Anđelinović, M., Pavković, A., Šegović, B.

Utjecaj pandemije COVID-19 na burzovne indekse odabranih zemalja intenzitet opada. Objašnjenje bi se moglo pronaći u činjenici da su dionici tržišta svoja negativna očekivanja već konzumirali i ugradili u pad cijena u prvom kvartalu 2020. godine. Može se dodati i laičko objašnjenje da su se dionici tržišta nakon početnog šoka, „naučili živjeti“ sa pandemijom i pripadajućim rizicima. Iznimka od toga trenda može se pronaći u kretanju burzovnog indeksa Eurozone koji je i u 2021. intenzivno reagirao na određene varijable.

\section{Literatura}

Albulescu, C. T. (2021). COVID-19 and the United States financial markets' volatility. Finance Research Letters, 38/2021. https://doi.org/10.1016/j.frl.2020.101699

Armien, B., Quiroz, W., \& Sah, B. (2008). Clinical Characteristics and National Economic Cost of the 2005 Dengue Epidemic in Panama. The American Journal of Tropical Medicine and Hygiene, 79(3): 364-371. https://doi.org/10.4269/ajtmh.2008.79.364

Ashraf, B. N. (2020). Stock markets' reaction to COVID-19: Cases or fatalities? Research in International Business and Finance, 54/2020. https://doi.org/10.1016/j.ribaf.2020.101249

Baker, S. R., Bloom, N., Davis, S. J., Kost, K., Sammon, M., \& Viratyosin, T. (2020). The Unprecedented Stock Market Impact of COVID-19. National Bureau of Economic Research Working Papers, No. w26945. https://doi.org/10.3386/w26945

Bannigidadmath, D., Narayan, P. K., Bach Phan, D. H., \& Gong, O. (2021). How stock markets reacted to COVID-19? Evidence from 25 countries. Finance Research Letters, Article in Press. https://doi.org/10.1016/j.frl.2021.102161

Bloom, D. E., \& Mahal, A. S. (1997). Does the AIDS Epidemic Threaten Economic Growth? Journal of Econometrics, 77(1): 105-124. https://doi.org/10.1016/S0304-4076(96)01808-8

Chen, M.P., Lee, C.C., Lin, Y.H., \& Chen, W.Y. (2018). Did the SARS Epidemic Weaken the Integration of Asian Stock Markets? Evidence from Smooth Time Varying Cointegration Analysis. Economic Research, 31(1): 908-926. https://doi.org/10.1080/1331677X.2018.1456354

Estrada, M. A. R., Park, D., Koutronas, E., Khan, A., \& Tahir, M. (2020). The Economic Impact of Massive Infectious and Congagious Diseases: The Case of Wuhan Coronavirus. Dostupno na: https://papers.ssrn.com/sol3/papers.cfm?abstract id=3533771 (18.09.2021.).

Federal Reserve Bank of St. Louis (2021). Federal Reserve Economic Data. Dostupno na: https://fred.stlouisfed.org/ (03.10.2021.).

Giudice, A. D., \& Paltrinieri, A. (2017). The Impact of the Arab Spring and the Ebola Outbreak on African Equity Mutual Fund Investor Decisions. Research in International Business and Finance, 41(C): 600-612. http://dx.doi.org/10.1016\%2Fj.ribaf.2017.05.004

Google Trends (2021). Dostupno na: https://trends.google.com/trends/?geo=HR (03.10.2021.).

He, O., Liu, J., Wang, S., \& Yu, J. (2020). The impact of COVID-19 on stock markets. Economic and Political Studies, 8(3): 275-288. https://doi.org/10.1080/20954816.2020.1757570

Investing.com (2021). Dostupno na: https://www.investing.com/ (01.10.2021.).

Just, M., \& Echaust, K. (2020). Stock market returns, volatility, correlation and liquidity during the 
COVID-19 crisis: Evidence from the Markov switching approach. Finance Research Letters, 37/2020. https://doi.org/10.1016/j.frl.2020.101775

Lyocsa, S.., Baumhol, E., Vyrost, T., \& Molnar, P. (2020). Fear of the coronavirus and the stock markets. Finance Research Letters, 36/2020. https://doi.org/10.1016/j.frl.2020.101735

NASDAQ (2021). Dostupno na: https://www.nasdaq.com/ (01.10.2021.).

Nippani, S., \& Washer, K. M. (2004). SARS: a Non-Event for Affected Countries' Stock Markets? Applied Financial Economics, 14(15): 1105-1110. https://doi.org/10.1080/0960310042000310579

Our World in Data (2021). Coronavirus Pandemic (COVID-19). Dostupno na: https://ourworldindata.org/ coronavirus (03.10.2021.).

Scherf, M., Matschke, X., \& Rieger, M. 0. (2021). Stock market reactions to COVID-19 lockdown: A global analysis. Finance Research Letters, Article in Press. https://doi.org/10.1016/j.frl.2021.102245

Senol, Z., \& Zeren, F. (2020). Coronavirus (COVID-19) and Stock Markets: The Effects of the Pandemic on the Global Economy. Eurasian Journal of Researches in Social and Economics, 4: 1-16.

Sergi, B. S., Harjoto, M. A., Rossi, F., \& Lee, R. (2021). Do stock markets love misery? Evidence from the COVID-19. Finance Research Letters, 42/2021. https://doi.org/10.1016/.jfl.2021.101923

Standard \& Poor's Global (2021).S\&P Dow Jones Indices. Dostupno na: https://www.spglobal.com/spdji/ en/ (01.10.2021.).

Trading Economics (2021). Dostupno na: https://tradingeconomics.com/ (01.10.2021.).

Wall Street Journal (2021). Dostupno na: https://www.wsj.com/ (01.10.2021.).

$\mathrm{Xu}$, L. (2021). Stock Return and the COVID-19 pandemic: Evidence from Canada and the US. Finance Research Letters, 38/2021. https://doi.org/10.1016/j.frl.2020.101872

Yahoo Finance (2021). Dostupno na: https://finance.yahoo.com/ (01.10.2021.).

Zagrebačka burza (2021). Dostupno na: https://zse.hr/ (03.10.2021.). 
